Original Research Article

\title{
Pharmacological evidence for the anticonvulsant activity of Tylophora indica in experimental animal models
}

\author{
Hafis T. K., Shyamjith Manikkoth*, Melinda Sequeira, Roopa P. Nayak
}

\begin{abstract}
Department of Pharmacology, Yenepoya Medical College, Yenepoya University, Mangalore, India
\end{abstract}

Received: 02 March 2017 Accepted: 11 March 2017

*Correspondence to:

Dr. Shyamjith Manikkoth, Email:

shyamjith@yenepoya.edu.in

Copyright: (C) the author(s), publisher and licensee Medip Academy. This is an openaccess article distributed under the terms of the Creative Commons Attribution NonCommercial License, which permits unrestricted noncommercial use, distribution, and reproduction in any medium, provided the original work is properly cited.

\begin{abstract}
Background: Epilepsy is a common neurological disorder. The antiepileptic drugs currently used are unable to manage seizures effectively and are associated with numerous adverse drug effects. Hence, there is a necessity of a newer anticonvulsant drug with high therapeutic index profile. The objective of this pre-clinical research was to investigate the role of Tylophora indica on Maximal electric shock [MES] and Pentylene tetrazole [PTZ] provoked convulsions in Wistar albino rats.

Methods: 36 Wistar albino rats were used for this study, after obtaining ethical clearance. The ethanolic extract of the leaves of Tylophora indica [TIEE] (100 $\mathrm{mg} / \mathrm{kg}$, p.o) was used to screen the anticonvulsant effect on MES and PTZ provoked convulsions in Wistar albino rats. In MES seizures, inhibition of the tonic hind limb extension and in PTZ seizures, extent of convulsions was noted. Results: TIEE $(100 \mathrm{mg} / \mathrm{kg}, \mathrm{p} . \mathrm{o})$ significantly $(\mathrm{p}<0.001)$ blocked the hind limb extension due to MES. The same dose also significantly $(\mathrm{p}<0.001)$ lessened the extent of convulsions induced by PTZ.

Conclusions: The data suggests that the ethanolic extract of Tylophora indica leaves produce its anticonvulsant effect via different mechanisms since it prevented the hind limb extension induced by MES and decreased the duration of convulsions produced by PTZ.
\end{abstract}

Keywords: Anticonvulsant, Convulsion, Maximal electric shock, Pentylene tetrazole, Tylophora indica, Wistar albino rats

\section{INTRODUCTION}

Epilepsy is a central nervous system disorder. This frequently seen chronic neurological disease is characterized by unpredictable and intermittent occurrence of a momentary alteration of behavior due to the distorted firing of brain neurons. ${ }^{1}$ The antiepileptic drugs presently available are not capable to control seizures efficiently and encompass various grave adverse effects. Keeping the above facts in mind, the significance of medicinal plants comes to the picture. India has an affluent source of an array of medicinal herbs. Phytoconstituents can play a key role in the treatment of epilepsy as they are well-known for high therapeutic index and comparatively low cost. ${ }^{2}$ Anticonvulsant properties of many plants is not scientifically proven.,
Enormous research works are to be carried out to establish the therapeutic properties of the unexplored plants and additional detailed investigations should be done to pin down the active ingredient of the plant accountable for the proven health benefit.

Tylophora indica is a climber seen in India. This plant of Asclepiadaceae family is traditionally used for the treatment of jaundice, inflammation and bronchial asthma. Different parts of this climber have many therapeutic uses. Many pre-clinical studies have proved the antiasthmatic, anti-inflammatory, antitumor, antianxiety, antirheumatic, analgesic, hepatoprotective and antioxidant activities of this plant. ${ }^{5-8}$ However there is no scientific data about the anticonvulsant activity of Tylophora indica till date. The aim of the present study 
was to evaluate the anticonvulsant property of ethanolic extract of Tylophora indica leaves in experimental animal models.

\section{METHODS}

\section{Drugs and chemicals}

Phenytoin sodium (Abbott Group, Acme formulation Pvt Ltd, Himachal Pradesh), Sodium valproate (Sun Pharma, Sikkim) were purchased from our hospital pharmacy in Mangalore. Pentylene tetrazole (Sigma Aldrich, China) was procured from Rajesh Chemicals, Mumbai.

\section{Instruments}

- Soxhlet apparatus to prepare the ethanolic extract.

- Electro-convulsiometer for induction of convulsions in animals.

\section{Tylophora indica ethanolic extract (TIEE)}

Tylophora indica plants were cultivated. Fresh leaves of Tylophora indica were collected and authenticated by a botanist. They were shade dried, and then made into coarse powder. 500 grams of the powder was extracted with ethanol (90\%) in a Soxhlet apparatus. The extract was concentrated on a water bath at a temperature below $60^{\circ} \mathrm{c}$. The ethanolic extract was suspended in distilled water. ${ }^{7}$ It was administered at a dose of $100 \mathrm{mg} / \mathrm{kg}$ body weight orally to the animals. The dose was selected based on the acute toxicity study.

\section{Animals}

Thirty six adult Wistar albino rats of both males and females weighing 150-200 g were used in this study after obtaining Institutional Animal Ethical Committee Clearance, Yenepoya University. The rats were maintained under standard conditions in the Animal House (CPCSEA approved, Reg No: 347) under Department of Pharmacology, Yenepoya University, Mangalore. The rats were provided food and water $a d$ libitum. The rats were maintained on a 12:12 hour lightdark cycle.

\section{Anticonvulsant activity}

\section{Maximal electroshock (MES) seizure}

Electrical stimulation was given using ear electrodes. The electrodes were dipped in saline before electrical stimulation. All animals were stimulated with $150 \mathrm{~mA}$ for 0.2 seconds, with constant voltage stimulators of $250 \mathrm{~V} .^{9}$

The animals were divided into three groups. Each group consisted of 3 males and 3 females $(n=6)$.

- Group I: Distilled Water (1 ml P.O for 10 days)+MES on $10^{\text {th }}$ day

- Group II: TIEE (100 mg/kg P.O for 10 days $)+$ MES on $10^{\text {th }}$ day

- Group III: Phenytoin (25mg/kg I.P for 10 days) + MES on $10^{\text {th }}$ day

On $10^{\text {th }}$ day, 1 hour after the test compounds were administered, convulsions were induced by electrical shock. The parameter observed was duration of tonic hind limb extension. ${ }^{9}$

\section{Pentylene tetrazole (PTZ) induced convulsion}

The animals were divided into three groups. Each group consisted of 3 males and 3 females $(n=6)$.

- Group I: Distilled Water (1 $\mathrm{ml}$ P.O for 10 days) + PTZ on 10th day

- Group II: TIEE (100 mg/kg P.O for 10 days) + PTZ on 10th day

- Group III: Sodium valproate $(75 \mathrm{mg} / \mathrm{kg}$ I.P for 10 days) + PTZ on 10th day

On $10^{\text {th }}$ day, 1 hour after the test compounds were administered, convulsions were induced by injecting PTZ $70 \mathrm{mg} / \mathrm{kg}$ I.P. The parameter noted was duration of convulsion. $^{9}$

\section{Statistical significance}

The results of the study is expressed as mean $\pm \mathrm{SD}, \mathrm{n}=6$. One Way ANOVA followed by Tukey Krammer multiple comparison tests was used to compare the data.

\section{RESULTS}

\section{Antiepileptic activity: MES induced seizures}

In the case of MES induced seizures there was no hind limb extension in TIEE and Phenytoin groups on comparing with the control group $(\mathrm{p}<0.001)$. There were 3 deaths in the control group. No mortality was observed in TIEE and Phenytoin groups (Table 1).

Table 1: Effect of TIEE on MES seizures.

\begin{tabular}{|llll|}
\hline Drugs & Dose $(\mathrm{mg} / \mathrm{kg})$ & Duration of Hind Limb extension in seconds (mean \pm SD) $\mathbf{n = 6}$ & Mortality \\
\hline Distilled Water & $10 \mathrm{ml} / \mathrm{kg}$ & $13.53 \pm 0.54$ & 3 \\
\hline TIEE & 100 & $0 \pm 0.000^{\mathrm{a}}$ & 0 \\
\hline Phenytoin & 25 & $0 \pm 0.000^{\mathrm{a}}$ & 0 \\
\hline
\end{tabular}

$\mathrm{n}=6$. ${ }^{\mathrm{a}} \mathrm{p}<0.001$, Considered highly significant on comparing TIEE and Phenytoin administered rats with the normal animals 
Table 2: Effect of TIEE on PTZ seizures

\begin{tabular}{|c|c|c|c|}
\hline Drugs & Dose (mg/kg) & Duration of convulsions in seconds (mean \pm SD) $n=6$ & Mortality \\
\hline Distilled Water & $10 \mathrm{ml} / \mathrm{kg}$ & $12.161 \pm 0.55$ & 3 \\
\hline TIEE & 100 & $1.01 \pm 0.31^{\mathrm{a}}$ & 0 \\
\hline Sodium Valproate & 75 & $1.26 \pm 0.14^{\mathrm{a}}$ & 0 \\
\hline
\end{tabular}

${ }^{\mathrm{a}} \mathrm{p}<0.0001$, Considered highly significant on comparing TIEE and Sodium valproate administered rats with the normal animals

\section{Antiepileptic activity: PTZ induced seizures}

In the case of PTZ induced seizures there was a significant decrease in the duration of convulsions in TIEE and Sodium Valproate groups on comparing with the control group. There were 3 deaths in the control group. No mortality was observed in TIEE and Sodium valproate groups (Table 2).

\section{DISCUSSION}

The results showed that the TIEE has significant anticonvulsant activity in MES and PTZ induced seizure models. Table-1 indicates that ethanolic extract of Tylophora indica leaves completely abolished the hind limb extension in MES models. Table 2 indicates that ethanolic extract of Tylophora indica leaves completely prevented the convulsions in PTZ induced seizure models.

Epilepsy, a neurological disorder is seen globally in approximately $1 \%$ of the population, affecting almost all ages and both sex. Some of the contributing factors of this neurological disorder include stroke and oxidative stress. $^{10,11}$ This pathological condition is differentiated by localized bursts of electrical over-activity in the cerebral hemispheres. ${ }^{12,13}$ Long-lasting plastic changes in the brain affecting the functions of neurotransmitter, the properties of receptors and channels, regulation of gene expression, synaptic re-organization and astrocyte activity lead to epilepsy. ${ }^{14}$

There are concrete evidences that an imbalance between the inhibitory and excitatory transmitters is involved in the etipathology of epilepsy. GABA (g-aminobutyric acid), the major inhibitory neurotransmitter in the brain, is vital for the overall balance between neuronal excitation and inhibition that is vital to normal brain function. Changes in GABA-A receptor subunits are strongly implicated in idiopathic generalized epilepsies. Drugs which reduce brain GABA content are often convulsants and drugs which elevates brain GABA content, have anticonvulsive properties. ${ }^{14-16}$

Glutamate being an excitatory transmitter has a major role in the beginning and spread of seizure activity. Unrelenting activation of glutamate receptor signaling pathways by wide release of glutamate in susceptible areas leads to neuronal damage through apoptosis. The NMDA and AMPA receptors of glutamate have a chief role in this disorder. Various animal studies showed that agents blocking these two glutamate receptors have powerful anticonvulsant property. ${ }^{17,18}$

Role of dopamine in epilepsy came into the picture based on the convulsiogenic effect of antipsychotics (i.e., dopaminergic D2-like antagonists). On the contrary, seizure inhibition has been seen in patients administered antiparkinsonian drugs such as pergolide and bromocriptine, both $\mathrm{D}_{2}$-agonists. ${ }^{19,20}$

The role of serotonin [5HT] in epilepsy had come into the picture due to the fact that, in patients with epilepsy, a common co-morbidity diagnosed is depression. Elevation in serotonin concentration has proved to have an inhibitory response to epileptic discharge and stabilizes the depressed mood disorder. Studies showed that mono amino oxidase inhibitors are effective in kindling model of epilepsy. Previous reports indicate that fluoxetine, a selective 5-hydroxytryptamine (5-HT) uptake inhibitor, has anticonvulsant effects. Another study has shown that sertraline decreased the intensity of autogenic seizures. Mutant mice lacking $5 \mathrm{HT}_{1 \mathrm{~A}}$ or $5 \mathrm{HT}_{2 \mathrm{C}}$ receptors have proved to have lower seizure threshold, implicating the role of respective 5HT receptors in epilepsy. ${ }^{13,21}$

Amongst the pre-clinical screening tests used for assessment of anticonvulsant activity, the MES and PTZ tests using rodents are the best validated methods. These two models mimic human generalized tonic-clonic seizures and absence seizures respectively. More over the above two seizure models are associated with oxidative damage. MES induced seizures are prevented by the drugs that blocks voltage gated sodium channels like Phenytoin or by the NMDA receptor antagonist like Felbamate. Whereas the drugs like Sodium valproate that block T-type $\mathrm{Ca}^{2+}$ channels in thalamus or the drugs has GABA mimetic activity like Diazepam prevents PTZ induced seizures. ${ }^{9}$

Abolition of MES induced seizures by the TIEE hint an activity against generalized tonic clonic seizures. The activity against PTZ induced convulsions envisages an activity against petitmal seizures.

Based on the above facts and results the anticonvulsant action of TIEE can be due to:

- Blockade of sodium channels since they abolish MES induced seizures. 
- Blockade of $\mathrm{T}$ type calcium channels in thalamus since it blocks PTZ induced seizures.

- GABA mimetic activity.

- Glutamate antagonistic property.

- Increase in monoaminergic activity.

- Antioxidant activity.

Phytochemical study revelaed that Tylophorinidine, an alkaloid is the active constituent present in the ethanolic extract of Tylophora indica. ${ }^{10}$ This alkaloid is an isoquinoline derivative. Isoquinoline compounds can inhibit monoamino oxidase enzyme (MAO) in brain. Being an isoquinoline derivative, Tylophorinidine can increase the levels of monoamines like dopamine and serotonin, and thereby preventing the MES and PTZ seizures. $^{22}$ This alkaloid also has antioxidant activity. ${ }^{22}$ By virtue of this free radical scavenging activity; this compound might have prevented MES and PTZ seizures.

\section{CONCLUSION}

The ethanolic extract of leaves of Tylophora indica will be beneficial in the management of grandmal and petitmal epilepsies. Tylophorinidine, an isoquinoline derivative may be responsible for its anticonvulsant property. Further studies are ongoing to elucidate the exact mechanism by which this plant acts as an anticonvulsant agent.

\section{Funding: No funding sources}

Conflict of interest: None declared

Ethical approval: The study was approved by the Institutional Ethics Committee

\section{REFERENCES}

1. Rasilingam D, Duraisamy S, Subramanian R.Anticonvulsant activity of bioflavonoid gossypin. Bangladesh J Pharmacol. 2009;4:51-4.

2. Joy AE, Kunhikatta SB, Manikkoth S. Anticonvulsant activity of ethanolic extract of Moringa concanensis leaves in swiss albino mice. Archives of Medicine and Health sciences. 2012;1(1):6-9.

3. Sheetal V, Singh SP. Current and future status of herbal medicines. Vet World. 2008;1(11):347-50.

4. Vaidya ADB, Devasagayam TPA. Current status of herbal drugs in India: an overview. J Clin Biochem Nutr. 2007;41(1):1-11.

5. Shyamjith M, Joy AE, Thyagaraju BM, Rao SN. Effect of Tylophora indica on haloperidol induced catalepsy in experimental animal models. Drug Invention Today. 2012;4(12):652-54.

6. Shyamjith M, Chandrashekar R, Rao SN. Antianxiety activity of Tylophora indica in experimental animal models.Int. J Res Ayur Pharm. 2013;4(1):127-29.

7. Jahas J, Ranjita K, ManikkothS, Rao SN. Protective role of Tylophora indica ethanolic extract on artesunate induced liver toxicity. Int J Appl Biol Pharm. 2014;5(4):206-10.
8. Dhiman M, Naik V, Kshirsagar R, Desai DC, Manju SL. Antioxidant activity of hydrochloride salt of tylophorinidine and tylophorinine isolated from aerial parts ofTylohoraindica. Int $\mathrm{J}$ Res Ayur Pharm. 2012;3(1):121-24.

9. Manikkoth S, Deepa B, Joy AE, Rao SN. Anti convulsant activity of Phyllanthus amarus in experimental animal models. Int J Appl Biol Pharm. 2011;2(4):144-49.

10. Goel R, Goel A. Effect of nebivolol on anticonvulsant property of sodium valproate along with neuropharmacological benefits in rodents models of epilepsy and behaviour in mice. Journal of Clinical and Experimental Neuroscience. 2013;1(1):1-9.

11. Pal A, Nayak S, Sahu PK, Swain T. Piperine protects epilepsy associated depression: a study on role of monoamines. Eur Rev Med Pharmacol Sci. 2011;15:1288-95.

12. Bozzi Y, Vallone D, Borrelli E. Neuroprotective role of dopamine against hippocampal cell death. J Neurosci. 2000;20(22):8643-49.

13. Stefulj J, Bordukalo-Niksic T, Hecimovic H, Demarin V, Jernej B. Epilepsy and serotonin (5HT): Variations of 5HT-related genes in temporal lobe epilepsy. Neuroscience Letters. 2010;478:29-31.

14. Wen-Juan Z, Ying-Hua M, Jian F, Zhen-Tong M, Li-He G. Increase in drug-induced seizure susceptibility of transgenic mice over expressing GABA transporter-1. Acta Pharmacol Sin. 2003;24(10):991-95.

15. Johnston GAR. GABA-A receptor channel Pharmacology. Curr Pharma Des. 2005;11:1867-85.

16. Abdul-ghani A. Changes in $\gamma$-aminobutyric acid during different stages of picrotoxin- induced seizure, and the effect of pretreatment with $\gamma$-acetylenic GABA and phenobarbital. J Biosci. 1989;14(1):63-67.

17. Lo"scher W. Pharmacology of glutamate receptor antagonists in the kindling model of epilepsy. Prog. Neurobiol. 1998;54:721-41.

18. Michael Rogawski A. Molecular targets versus models for new antiepileptic drug discovery. Epilepsy Res. 2006;68(1):22-8.

19. Farjo IB, McQueen JK. Dopamine agonist and cobaltinduced epilepsy in rats. Br J Pharmac. 1979; 67:353360. 262Yuri Bozzi and Emiliana Borrelli. The role of dopamine signaling in epileptogenesis. Front Cell Neurosci. 2013;7(157):1-7.

20. Yan Q, Jobe PC, Dailey JW. Further evidence of anticonvulsant role for 5-hydroxytryptamine in genetically epilepsy prone rats. $\mathrm{Br} \mathrm{J}$ of Pharmacol. 1995;115:1314-18.

21. Shyamjith M, Deepa B, Melinda S, Anu EJ, Roysten R. Assessment of brain dopamine levels to evaluate the role of Tylophora indica ethanolic extract on alcohol induced anxiety in Wistar albino rats. J Young Pharm. 2016;8(2):1-10.

Cite this article as: Hafis TK, Manikkoth SK, Sequeira M, Nayak RP. Pharmacological evidence for the anticonvulsant activity of Tylophora indica in experimental animal models. Int J Basic Clin Pharmacol 2017;6:750-3. 